\title{
Comparative analyses of estimated and calorimetrically determined energy balance in high-yielding dairy cows
}

\author{
S. Erdmann, ${ }^{1}$ M. Derno, ${ }^{2}$ C. T. Schäff, ${ }^{2}$ S. Börner, ${ }^{2}$ U. Kautzsch, ${ }^{2}$ B. Kuhla, ${ }^{2}$ H. M. Hammon, ${ }^{2}$ A. Tuchscherer, ${ }^{3}$ \\ and M. Röntgen ${ }^{1 *}$ \\ ${ }^{1}$ Institute of Muscle Biology and Growth, Leibniz Institute for Farm Animal Biology (FBN), Wilhelm-Stahl-Allee 2, 18196 Dummerstorf, Germany \\ ${ }^{2}$ Institute of Nutritional Physiology “Oskar Kellner," Leibniz Institute for Farm Animal Biology (FBN), Wilhelm-Stahl-Allee 2, 18196 Dummerstorf, \\ Germany \\ ${ }^{3}$ Institute of Genetics and Biometry, Leibniz Institute for Farm Animal Biology (FBN), Wilhelm-Stahl-Allee 2, 18196 Dummerstorf, Germany
}

\section{ABSTRACT}

Our aim was to compare the energy balance estimated (EBest) according to equations published by various energy feeding systems (German Society for Nutrition Physiology, French National Institute for Agricultural Research, and US National Research Council) and the EB calculated by use of calorimetrically measured heat production (EBhp) of 20 high-yielding ( $\geq 10,000$ $\mathrm{kg} / 305 \mathrm{~d}$ ) German Holstein cows at -4 (pregnant, nonlactating) and $2 \mathrm{wk}$ (early lactation) relative to parturition. In addition to heat production, feed and water intake, physical activity (including standing-lying behavior), body weight, body condition score, body temperature, plasma concentrations of fatty acids and $\beta$-hydroxybutyrate, milk yield, and milk composition were measured to characterize the metabolic status. The EBhp was balanced [2.74 \pm 4.09 MJ of metabolizable energy $(\mathrm{ME}) / \mathrm{d}$; \pm standard error] before calving, but strongly negative $(-84.7 \pm 7.48 \mathrm{MJ}$ of $\mathrm{ME} / \mathrm{d})$ at wk 2 of lactation. At both time points, EBhp and EBest differed significantly. On average, the equations overestimated the antepartum EB by $33 \mathrm{MJ}$ of $\mathrm{ME} / \mathrm{d}$ and underestimated the postpartum negative $\mathrm{EB}$ by $67 \mathrm{MJ}$ of $\mathrm{ME} / \mathrm{d}$, respectively. Because the same $\mathrm{ME}$ intake and energy-corrected milk values were used for calculation of EBest and EBhp in our study, we considered that the factors ( 0.488 to $0.534 \mathrm{MJ}$ of $\mathrm{ME} / \mathrm{kg}^{0.75}$ ) currently used to calculate the ME requirements for maintenance probably underestimate the needs of highyielding dairy cows, particularly during early lactation. In accord, heat production values determined under standard conditions of thermoneutrality and locomotion restriction amounted to $0.76 \pm 0.02 \mathrm{MJ}$ of $\mathrm{ME} /$

Received May 4, 2018.

Accepted December 19, 2018.

*Corresponding author: roentgen@fbn-dummerstorf.de $\mathrm{kg}^{0.75}$ (4 wk antepartum) and $1.02 \pm 0.02 \mathrm{MJ}$ of ME/ $\mathrm{kg}^{0.75}$ (2 wk postpartum), respectively. The expected positive correlation between EBhp and DMI was observed in pregnant cows only; however, a bias of 26 MJ of ME/d between mean actual energy intake and ME intake predicted according to German Society for Nutrition Physiology was found in cows at wk 4 antepartum. At both investigated time points, mobilization of tissue energy reserves (reflected by plasma fatty acid concentration) was related to EBhp. In early lactating cows, metabolic body weight $\left(\mathrm{kg}^{0.75}\right)$ and the percentage of milk fat showed the strongest correlation (correlation coefficient $=-0.70$ and -0.73 ) to EBhp. Our findings must be taken into account when experimental data are interpreted because the true energy status might be significantly overestimated when EBest is used.

Key words: heat production, maintenance requirement, respiration chamber, dairy cow

\section{INTRODUCTION}

Selective breeding has led to an enormous increase in milk yield in high-yielding dairy cows of the German Holstein breed. Moreover, improvements of cow comfort, management, and feeding strategies have added to this tremendous increase in performance (Veerkamp et al., 2000). Nevertheless, health problems (Collard et al., 2000) and reduced reproductive fitness (Butler, 2000; Wathes et al., 2009) have been linked to high milk production (Harrison et al., 1990) and, specifically, to the development of an excessive negative energy balance (NEB) after calving (Murphy et al., 2009; Gross et al., 2011).

Energy balance (EB) is defined as the difference of energy intake and energy expenditure plus excretion (Wylie et al., 2008). Thus, NEB develops when the energy requirements for maintenance and performance are not covered by the energy consumption of feed (amount and composition of diet; Gross et al., 2011). Although 
feed intake increases during early lactation, this is insufficient to cover the demands of high milk production (Drackley, 2002; Grummer et al., 2004; Hammon et al., 2009). The developing period of NEB is characterized by the mobilization of body fat and protein, the loss of BW, and increased blood concentrations of fatty acids (Tamminga et al., 1997; Wylie et al., 2008; Gross et al., 2011). This condition has been linked to a higher incidence of metabolic diseases, such as ketosis and fatty liver (Reist et al., 2002; LeBlanc et al., 2006), and to immunosuppression (Collard et al., 2000; Goff, 2006). Negative energy balance has also been associated with delayed time to first ovulation and to first breeding and with reduced pregnancy rates (reduced reproductive success; Chilliard et al., 1998; Lopez et al., 2004).

Observation of the energy status by using indicators such as BCS (Edmonson et al., 1989; Rastani et al., 2001), fat-to-protein ratio in milk (Heuer et al., 1999; de Vries and Veerkamp, 2000), or metabolites (e.g., fatty acids and BHB; van Knegsel et al., 2007) is thus an important aspect of herd management. The ME requirements for maintenance (MEm), physical activity, gestation, and milk are estimated based on country-specific equations given, for example, by the German Society for Nutrition Physiology (GfE, 2001), the French National Institute for Agricultural Research (INRA, 2007), the British Agricultural and Food Research Council (AFRC, 1993), and the NRC (2001). The basis for feed energy evaluation is the ME, defined as gross energy minus energy in feces, urine, and methane. Net energy systems are derived from the $\mathrm{ME}$ and involve the partial efficiency of the utilization of feed ME for (1) maintenance, (2) milk production, (3) live weight gain, and (4) the efficiency of mobilized tissue energy for lactation (Kebreab et al., 2003; Gruber et al., 2008). For dairy cattle, these values have been derived from calorimetric measurements used to determine the net energy requirement for maintenance either from fasting dry cows and beef steers (summarized in GfE, 2001) or from the linear regression of milk energy output against ME intake (MEI; Schiemann et al., 1971; Moe et al., 1972; Van Es, 1975). Over $20 \mathrm{yr}$ ago, Yan et al. (1997a) pointed out that the partition of dietary ME into milk had increased by 12 to $15 \%$ over the value given in studies used to generate the existing recommendations. Therefore, our objective in the present study was to calculate the energy balance of dairy cows based on calorimetrically measured heat production data (EBhp) at $4 \mathrm{wk}$ before (pregnant, nonlactating) and 2 wk after calving (lactating) and to compare it with values estimated according to equations published by various energy feeding systems [estimated $\mathrm{EB}$ (EBest); GfE, 2001; NRC, 2001; INRA, 2007].

\section{MATERIALS AND METHODS}

This study was part of a larger joint research project (DFG project: KU 1956/3-1; HA 4372/6-1; SCHW 642/7-1) and was conducted with the approval of the Animal Care Committee of the Ministry of Nutrition, Agriculture, Forestry, and Fishery, Schwerin, State Mecklenburg-Western Pomerania, Germany (M-V/ TSD/7221.3-2.1-021/09).

\section{Animals and Diet}

Experiments were performed with 20 multiparous German Holstein cows (second to fourth lactation; 5 blocks with 4 cows per block) born and raised at the farm of Griepentrog KG (Steinhagen, Germany). Body weight and BCS (scale 1-5) were determined weekly. All cows were kept in tiestalls, had a milk yield of $\geq 10,000 \mathrm{~kg} / 305 \mathrm{~d}$, and had been dried off 7 wk before expected calving.

Cows were fed ad libitum a far-off diet or earlylactation diet twice daily at 0700 and $1500 \mathrm{~h}$ and had free access to water and mineral salt blocks. From d 21 until calving, cows were fed a close-up diet. All diets were given as TMR and prepared to meet the nutrient recommendations of the GfE (2001). Their ingredients and average nutrient, in vitro enzyme-soluble organic substance (ELOS; Pries et al., 2009), ME, $\mathrm{NE}_{\mathrm{L}}$, and utilizable CP contents (GfE, 1997, 2009) are summarized in Table 1, which gives average values over all diets used during the experimental trials. The $\mathrm{NE}_{\mathrm{L}}(\mathrm{MJ} /$ $\mathrm{kg}$ of DM) values in Table 1 result from conversion of estimated ME (MJ/kg of DM) values of feeds by using the equation given in GfE (2009):

$$
\mathrm{NE}_{\mathrm{L}}=\mathrm{ME}[0.46+12.38 \mathrm{ME} /(1,000-\mathrm{CA})],
$$

where $\mathrm{CA}=$ crude ash.

Samples of grass and corn silages, hay, and the 3 TMR were collected once a week over the experimental period for analysis of DM content (VDLUFA, 1993; 3 $\mathrm{h}$ in drying chamber at $105^{\circ} \mathrm{C}$ ). Additional samples of hay, grass, and corn silages were taken every 2 wk and of the TMR every 3 wk for nutrient analysis. The nutrient contents of the samples were estimated according to the Weender analytical method following procedures of VDLUFA (1993; for crude ash, ashing of dried samples for $5 \mathrm{~h}$ in a muffle furnace at $600^{\circ} \mathrm{C}$; for $\mathrm{CP}$, Kjeldahl method, $\mathrm{N} \times 6.25$; and for crude fat, Soxhlet petrol ether extraction). According to Schmidt et al. (2005), the contents in starch were measured by HPLC (Shimadzu, Kyoto, Japan) after enzymatic hydrolysis of feed samples using a Thermamyl 120 (Novo Nordisk 
A/S, Bagsværd, Denmark). The NDF and ADF contents of the TMR samples were analyzed according to VDLUFA (1993) methods (following Van Soest et al., 1991). The ELOS has been determined in vitro following the method described in VDLUFA (1993; cellulase method).
Data summarized by Van der Honing and Alderman (1988) show that differences between feed ME values estimated according to various country-specific procedures and regression equations are rather small. Nevertheless, it must be stated that, between countries, small differences will exist at least for single feedstuffs,

Table 1. Ingredients and chemical composition (means $\pm \mathrm{SE}$ ) of the far-off dry period, close-up dry period, and early-lactation diets fed during the study to dairy cows

\begin{tabular}{|c|c|c|c|}
\hline \multirow[b]{2}{*}{ Component } & \multicolumn{3}{|c|}{ Diet } \\
\hline & $\begin{array}{c}\text { Far-off } \\
\text { dry period }\end{array}$ & $\begin{array}{c}\text { Close-up } \\
\text { dry period }\end{array}$ & $\begin{array}{c}\text { Early } \\
\text { lactation }\end{array}$ \\
\hline \multicolumn{4}{|l|}{ Ingredient, $\mathrm{g} / \mathrm{kg}$ of $\mathrm{DM}$} \\
\hline Grass silage & $744 \pm 24$ & $302 \pm 9.1$ & $202 \pm 16$ \\
\hline Corn silage & $37 \pm 12$ & $399 \pm 9.9$ & $350 \pm 18$ \\
\hline Barley straw & $115 \pm 1.7$ & $54 \pm 3.3$ & $16 \pm 0.6$ \\
\hline Meadow hay ${ }^{2}$ & $92 \pm 4.1$ & $39 \pm 4.0$ & $26 \pm 4.2$ \\
\hline Concentrate $^{3,4}$ & $1.4 \pm 0.6$ & $124 \pm 1.8$ & $296 \pm 6.3$ \\
\hline Molassed sugar beet pulp ${ }^{5}$ & $4.1 \pm 1.2$ & $5.5 \pm 2.6$ & $62 \pm 4.8$ \\
\hline Extracted rapeseed meal & & $45 \pm 2.6$ & $32 \pm 8.6$ \\
\hline Mineral feed ${ }^{6,7}$ & $7.7 \pm 0.1$ & $1.8 \pm 0.3$ & $6.7 \pm 0.3$ \\
\hline Nonlactating mineral feed with anionic salts ${ }^{8}$ & & $12 \pm 0.7$ & \\
\hline Cattle salt ${ }^{9}$ & & $1.0 \pm 0.1$ & $0.7 \pm 0.2$ \\
\hline Propylene glycol ${ }^{10}$ & & $16 \pm 0$ & $8.8 \pm 0$ \\
\hline \multicolumn{4}{|l|}{ Chemical analysis } \\
\hline $\mathrm{DM}, \mathrm{g} / \mathrm{kg}$ & $931 \pm 4.2$ & $943 \pm 5.9$ & $942 \pm 7.4$ \\
\hline Crude ash, $\mathrm{g} / \mathrm{kg}$ of $\mathrm{DM}$ & $83 \pm 1.4$ & $73 \pm 5.3$ & $69 \pm 3.1$ \\
\hline Crude fat, $\mathrm{g} / \mathrm{kg}$ of $\mathrm{DM}$ & $40 \pm 0.5$ & $33 \pm 1.4$ & $30 \pm 1.3$ \\
\hline NDF, g/kg of DM & $354 \pm 3.9$ & $317 \pm 10.0$ & $298 \pm 9.4$ \\
\hline $\mathrm{ADF}, \mathrm{g} / \mathrm{kg}$ of $\mathrm{DM}$ & $202 \pm 3.0$ & $137 \pm 7.3$ & $140 \pm 3.1$ \\
\hline Starch, $\mathrm{g} / \mathrm{kg}$ of $\mathrm{DM}$ & $104 \pm 3.5$ & $186 \pm 4.5$ & $208 \pm 4.3$ \\
\hline ELOS, ${ }^{11} \mathrm{~g} / \mathrm{kg}$ of TS & $617 \pm 7.2$ & $691 \pm 6.9$ & $754 \pm 4.4$ \\
\hline Utilizable $\mathrm{CP}, \mathrm{g} / \mathrm{kg}$ of $\mathrm{DM}$ & $126 \pm 1.4$ & $137 \pm 0.4$ & $163 \pm 0.5$ \\
\hline $\mathrm{ME},{ }^{11} \mathrm{MJ} / \mathrm{kg}$ of $\mathrm{DM}$ & $9.7 \pm 0.1$ & $10.8 \pm 0.1$ & $11.8 \pm 0.1$ \\
\hline $\mathrm{NE}_{\mathrm{L}},{ }^{11} \mathrm{MJ} / \mathrm{kg}$ of $\mathrm{DM}$ & $5.8 \pm 0.1$ & $6.5 \pm 0.1$ & $7.1 \pm 0.1$ \\
\hline
\end{tabular}

${ }^{1}$ Far-off and close-up dry periods were from 7 to 4 and 3 to 1 wk before calving, respectively.

${ }^{2}$ Average crude nutrient contents, in $\mathrm{g} / \mathrm{kg}$ of DM: CP, 125; crude fiber, 337; crude fat, 15; sugar, 60. Average ME: $9.4 \mathrm{MJ} / \mathrm{kg}$ of $\mathrm{DM}$, average $\mathrm{NE}_{\mathrm{L}}: 5.2 \mathrm{MJ} / \mathrm{kg}$ of $\mathrm{DM}$.

${ }^{3}$ Concentrate MF 2000 (Vollkraft Mischfutterwerke GmbH, Güstrow, Germany): 33\% extracted soy meal, 20\% corn, $17 \%$ wheat gluten, $13 \%$ wheat, $8 \%$ extracted rapeseed meal, $5 \%$ sugar beet pulp, $2 \%$ sodium hydrogen carbonate, $1.3 \%$ calcium carbonate, $0.2 \%$ sodium chloride. $\mathrm{NE}_{\mathrm{L}}: 8.0 \mathrm{MJ} / \mathrm{kg}$ of DM, utilizable protein: $204 \mathrm{~g} /$ $\mathrm{kg}$ of DM.

${ }^{4}$ Concentrate Universal 18/3 (Vollkraft Mischfutterwerke $\mathrm{GmbH}$ ): 20-40\% cereals (triticale, rye, wheat, barley), $25 \%$ rapeseed expeller, lower contents of malt-germs, wheat gluten, wheat bran, peeled oat bran, beet pulp chips, molasses and glycerin, minerals, and vitamins. $\mathrm{NE}_{\mathrm{L}}: 6.7 \mathrm{MJ} / \mathrm{kg}$ of DM, utilizable protein: $160 \mathrm{~g} /$ $\mathrm{kg}$ of DM.

${ }^{5}$ Trockenschnitzel (Arp, Thordsen, Rautenberg GmbH \& Co KG, Sollerupmühle, Germany): minerals, NE $\mathrm{L}_{\mathrm{L}}: 7.3$ $\mathrm{MJ} / \mathrm{kg}$ of DM, utilizable protein: $153 \mathrm{~g} / \mathrm{kg}$ of DM.

${ }^{6}$ Rinderstolz 9235 far-off and close-up dry period (Salvana Tiernahrung GmbH, Sparrieshoop, Germany): $75 \%$ crude ash, $4.5 \%$ calcium, $6 \%$ phosphorus, $10 \%$ sodium, $12 \%$ magnesium, vitamins.

${ }^{7}$ Rinderstolz 9522 lactation (Salvana Tiernahrung GmbH): 92\% crude ash, 20\% calcium, 5\% phosphorus, $6 \%$ magnesium, $8 \%$ sodium, vitamins.

${ }^{8}$ Anionen-Mix 1141 (Salvana Tiernahrung $\mathrm{GmbH}$ ): 14\% calcium, 12.5\% sulfur, 12\% chlorine, 10\% magnesium, $2 \%$ phosphorus, vitamins.

${ }^{9}$ SOLSEL Mineralleckstein mit Kupfer (esco - European Salt Company GmbH \& Co, KG, Hannover, Germany): $37 \%$ sodium, $1.6 \%$ calcium, $0.6 \%$ magnesium.

${ }^{10}$ Propylenglykol USP (Dr. Pieper Technologie- und Produktentwicklung GmbH, Wuthenow, Germany).

${ }^{11}$ Dietary ME concentrations were estimated from analyzed crude nutrient amounts and in vitro enzymesoluble organic substance (ELOS) according to Pries et al. (2009) using the equation published by the German Society for Nutrition Physiology (GfE, 2009). From estimated ME concentrations, $\mathrm{NE}_{\mathrm{L}}$ of diets was calculated using the equation given by GfE (2009). Values in Table 1 are means over all diets used during the experimental trials. For energy balance estimation ME intake of individual cows was calculated using actual estimated ME values of the current diets. 
specifically for forages, due to different composition and digestibility. Here, procedures described in GfE (2009) were used to estimate ME (MJ/kg of DM) concentrations of rations from determined crude nutrient and ELOS amounts according to the following equation (Pries et al., 2009):

$$
\begin{aligned}
\mathrm{ME} & =9.67-0.01698 \times \text { crude ash }+0.00340 \times \mathrm{CP} \\
& +0.01126 \times \text { crude fat }+0.00123 \times \text { starch } \\
& -0.00097 \times \mathrm{NDFom}+0.00360 \times \text { ELOS }
\end{aligned}
$$

with crude ash, $\mathrm{CP}$, crude fat, starch, NDF on an OM basis (NDFom), and ELOS in grams per kilogram of $\mathrm{DM}$; megajoules per gram is the unit for the regression coefficients. As described by Pries et al. (2009), for equation development, digestibility (via classical balance studies with sheep) of OM (in average 84\%), crude nutrients, starch, and sugar has been determined for 349 ruminant compound feeds (312 of them for milk cows). Thus, it takes differences (e.g., in digestibility or composition; high concentrate content) of the TMR into consideration.

Metabolic protein supply of the TMR was estimated by calculation of the utilizable $\mathrm{CP}(\mathrm{g} / \mathrm{kg}$ of $\mathrm{DM})$, which is the sum of microbial CP and undegraded feed protein (UDP) entering the duodenum (Melesse, 2012). The following equation (GfE, 1997) was used:

$$
\begin{gathered}
\text { Utilizable } \mathrm{CP}=\{11.93-[6.82 \times(\mathrm{UDP} / \mathrm{CP})]\} \\
\times \mathrm{ME}+(1.03 \times \mathrm{UDP}) .
\end{gathered}
$$

\section{Experimental Design}

The experimental trials were performed in 4 climatecontrolled $\left(15^{\circ} \mathrm{C}, 70 \%\right.$ humidity), open-circuit respiration chambers for measurements of energy expenditure with a volume of $20 \mathrm{~m}^{3}$ and space enough for the individual animal to stand or to lie down (Derno et al., 2009). During wk 7 to 5 antepartum (ap), the cows were adapted to handling and staying in the respiration chambers. Habituation (criteria: eating, drinking, ruminating, lying down, body temperature) was performed at least 3 times, and the duration of stay was increased from $1 \mathrm{~h}$ on $\mathrm{d} 1$ to 3 to $4 \mathrm{~h}$ on $\mathrm{d} 4$. No animal needed longer than $4 \mathrm{~d}$ to habituate.

During week 4 ap and 2 postpartum (pp), cows were transferred to the respiration chambers for $3 \mathrm{~d}$. The measurements started on the second day at $0630 \mathrm{~h}$ and gas exchange $\left(\mathrm{O}_{2}\right.$ consumption, $\mathrm{CO}_{2}$ and $\mathrm{CH}_{4}$ production), food and water intake (WI), and physical activity (including standing-lying behavior) were continuously determined in 6-min intervals for $24 \mathrm{~h}$. The cows were weighed immediately before entering and after leaving the chambers on balances in front of the chambers. The body temperature was measured after the second feeding $(1500 \mathrm{~h})$ and once the measurements were complete. The cows were milked twice daily at 0630 and $1630 \mathrm{~h}$ on a mobile milking system, and the operative wore a facemask coupled to outside air via flexible tubes. Milk yield was measured subsequently. Milk samples pooled daily from 1 morning and 1 afternoon milking were taken and analyzed for milk fat, protein, and lactose by the State Inspection Association for Performance and Quality Testing Mecklenburg-Western Pomerania e.V. (Güstrow, Germany) by infrared absorption (MilkoScan, Foss, Hillerød, Denmark).

\section{Indirect Calorimetry, Feed Intake, WI, and Behavioral Data}

Gas concentrations for $\mathrm{O}_{2}, \mathrm{CO}_{2}$, and $\mathrm{CH}_{4}$ were measured continuously in 6-min intervals. Gas samples were passed through infrared absorption-based analyzers (UNOR 610, Maihak AG, Hamburg, Germany) for the determination of $\mathrm{CO}_{2}$ and $\mathrm{CH}_{4}$ content and through a paramagnetic analyzer (OXYGOR 610, Maihak AG) for the measurement of $\mathrm{O}_{2}$ content.

The standing and lying times of the cows were registered by a photoelectric switch (SA1E, IDEC Elektrotechnik GmbH, Hamburg, Germany). Other physical activity was detected by a modified infrared-based motion detector (IS 120, Steinel, Herzebrock-Klarholz, Germany), converting any movements of the animals into impulses.

The individual feed intake of all cows was recorded automatically by measuring feed disappearance from the chamber feed bin (maximum capacity: $40 \mathrm{~kg}$ of $\mathrm{OM}$ ) via a scale connected to an electronic registration device (PAARI, Erfurt, Germany). Water intake was registered by water counters equipped with electromechanical registration (Elster Messtechnik, Lampertheim, Germany).

All measured variables (gas concentrations for $\mathrm{O}_{2}$, $\mathrm{CO}_{2}$, and $\mathrm{CH}_{4}$, air flow rate, feed disappearance from the feed bin, WI, temperature and relative humidity in and behind the chamber, standing and lying times, activity counts, and air pressure) were sent to an acquisition system (Simatic, Siemens, München, Germany) and collected by purpose-adapted software (WinCC, Version 5.1, SP 2, Siemens). The Delphi-based (Delphi 2007, San Francisco, CA) software was programmed in our group (Copyright H. Scholze, Leibniz Institute for Farm Animal Biology, Dummerstorf, Germany) to enable the automatic calculation of heat production (HP) and the collection of all measured data in Excel 2010 (Microsoft Corp., Redmond, WA) files. 


\section{Blood Sampling and Analysis}

Cows were equipped with indwelling jugular catheters on the day before the trial started. Extension tubing was used to take blood samples (hourly from 0920 $\mathrm{h}$ to $1420 \mathrm{~h}$ ) from outside the respiration chambers into Fe-Fluoride monovettes (Sarstedt, Nümbrecht, Germany) and immediately placed on ice. Blood samples were centrifuged $\left[2,700 \mathrm{rpm}(4,000 \times \mathrm{g}), 4^{\circ} \mathrm{C}\right]$ for 20 min, and the supernatants were stored at $-80^{\circ} \mathrm{C}$ until analysis. Plasma concentrations of fatty acids and BHB were measured by routine analysis (Cobas Mira, Clinic for Cattle, Stiftung Tierärztliche Hochschule Hannover, Hannover, Germany) with kits from Wako Chemicals (NEFA kit 434-91795; Wako Chemicals, Richmond, VA) and Randox Laboratories (BHB kit RB 998; Randox Laboratories, Crumlin, UK), respectively.

\section{Calculations}

Measurements of HP, feed intake, DM, nutrient, and ELOS contents of the diet, BW, milk yield, and milk composition were used to calculate EBhp and EBest. For both, EBhp and EBest, DMI (kg/d) was calculated according to measured feed intake $(\mathrm{kg} / \mathrm{d}) \times \mathrm{DM}$ $(\%) / 100(\%)$, and MEI (MJ of ME/d) according to estimated $\mathrm{ME}(\mathrm{MJ} / \mathrm{kg}$ of $\mathrm{DM})$ of the ration $\times \mathrm{DMI}$. The MEI of individual cows was calculated using actual ME concentrations of the current diets estimated according to the GfE (2009) procedure, as described in the Animals and Diet section. Thus, used ME values are unequal to the average values summarized in Table 1.

In most countries, the calculation of EBest is based on net energy for lactation systems. Here, to ensure the comparability of EBhp and EBest, we converted maintenance requirements from megajoules of $\mathrm{NE}_{\mathrm{L}}$ to megajoules of ME per day by using the following equation with metabolic body weight $\left(\mathbf{M B W} ; \mathrm{kg}^{0.75}\right)$ :

$$
\begin{gathered}
0.293\left(\mathrm{MJ} \text { of } \mathrm{NE}_{\mathrm{L}}\right) \times \mathrm{MBW}= \\
0.488(\mathrm{MJ} \text { of } \mathrm{ME}) \times \mathrm{MBW} .
\end{gathered}
$$

The EBhp was calculated by using equations [2] and [3] for pregnant and lactating cows, respectively:

$$
\begin{gathered}
\operatorname{EBhp}(\mathrm{MJ} \text { of ME/d) = MEI }(\mathrm{MJ} \text { of ME/d) } \\
-\mathrm{HP}(\mathrm{kJ} / \mathrm{d}) / 1,000 ;
\end{gathered}
$$

and

$$
\begin{gathered}
\operatorname{EBhp}(\mathrm{MJ} \text { of ME/d) }=\text { MEI }(\mathrm{MJ} \text { of ME/d) } \\
-[3.14 \times \mathrm{ECM}(\mathrm{MJ} / \mathrm{d})+\mathrm{HP}(\mathrm{kJ} / \mathrm{d}) / 1,000] .
\end{gathered}
$$

Heat production was calculated from gas exchange data according to Brouwer (1965) as

$$
\begin{gathered}
\mathrm{HP}(\mathrm{kJ} / \mathrm{d})=16.18 \mathrm{O}_{2}(\mathrm{~L} / \mathrm{d})+5.02 \mathrm{CO}_{2}(\mathrm{~L} / \mathrm{d}) \\
-2.17 \mathrm{CH}_{4}(\mathrm{~L} / \mathrm{d})-5.99 \mathrm{~N}_{\mathrm{u}}(\mathrm{g} / \mathrm{d}) .
\end{gathered}
$$

The urinary nitrogen excretion $\left(\mathrm{N}_{\mathrm{u}}\right)$ was not measured but, as in our previous studies (Börner et al., 2013b; Derno et al., 2013), it was set to $50 \mathrm{~g} / \mathrm{d}$. Although real urinary nitrogen excretion may amount to higher values of, for example, 75 to $150 \mathrm{~g} / \mathrm{d}$ when estimated using different regression equations (Dijkstra et al., 2013), we hereby accepted an error of $0.4 \%$ in in the absolute values of HP.

The milk energy output $\left(\mathrm{E}_{1} ; \mathrm{MJ} / \mathrm{d}\right)$ was estimated from the equation reported by Reist et al. (2002) considering the caloric values $(\mathrm{MJ} / \mathrm{g}$ ) and the measured contents $(\mathrm{g} / \mathrm{kg})$ of crude fat, $\mathrm{CP}(\mathrm{N} \times 6.83)$, and lactose and milk yield $(\mathrm{kg} / \mathrm{d})$ :

$$
\begin{aligned}
\mathrm{E}_{\mathrm{l}}=( & 0.038 \times \text { crude fat }+0.024 \times \mathrm{CP}+0.017 \\
& \times \text { lactose }) \times \text { milk yield }
\end{aligned}
$$

To estimate ECM, milk energy output was then divided by the caloric value $(3.14 \mathrm{MJ} / \mathrm{kg}$ ) of ECM (per $\mathrm{kg}: 40 \mathrm{~g}$ of fat, $34 \mathrm{~g}$ of protein, and $48 \mathrm{~g}$ of lactose).

The EBest for pregnant [equations 6, 7, and 8] and lactating [equations 9, 10, and 11] cows were calculated according to equations published by the GfE (2001), NRC (2001), and INRA (2007) (summarized in Gruber et al., 2008). As described in the Animals and Diet section, MEI calculated from ME values estimated according to GfE (2009) procedures and from measured individual feed intake of cows was equally used in equations [6] to [11]:

$$
\begin{aligned}
\text { GfE: } \mathrm{EB} & (\mathrm{MJ} \text { of } \mathrm{ME} / \mathrm{d})=\mathrm{MEI}-(0.488 \times \mathrm{MBW} \\
& \left.+0.044 \times \mathrm{e}^{0.0165 \times \text { day of conception }}\right)
\end{aligned}
$$

NRC: EB $(\mathrm{MJ}$ of ME/d) $=\mathrm{MEI}-(0.534 \times \mathrm{MBW}$

$$
\left.+0.044 \times \mathrm{e}^{0.0165 \times \text { day of conception }}\right) \text {; }
$$

INRA: $\mathrm{EB}(\mathrm{MJ}$ of $\mathrm{ME} / \mathrm{d})=\mathrm{MEI}-(0.486 \times \mathrm{MBW}$

$$
\left.+0.044 \times \mathrm{e}^{0.0165 \times \text { day of conception }}\right) \text {; }
$$

GfE: $\mathrm{EB}(\mathrm{MJ}$ of $\mathrm{ME} / \mathrm{d})=\mathrm{MEI}-(3.14 \times \mathrm{ECM}$

$$
+0.488 \times \mathrm{MBW})
$$

NRC: EB $(\mathrm{MJ}$ of ME/d) $=\mathrm{MEI}-(3.14 \times \mathrm{ECM}$

$$
+0.534 \times \mathrm{MBW}) \text {; }
$$


and

$$
\begin{gathered}
\text { INRA: EB }(\mathrm{MJ} \text { of ME/d) }=\mathrm{MEI}-(3.14 \times \mathrm{ECM} \\
+0.486 \times \mathrm{MBW}) .
\end{gathered}
$$

The fermentative $\mathrm{CO}_{2}$, an estimate of rumen fermentation activity, was calculated according to Chwalibog et al. (1996):

$$
\text { Fermentative } \mathrm{CO}_{2}(\mathrm{~L})=1.7 \times \mathrm{CH}_{4} \text {. }
$$

The factor 1.7 takes into account differences in diet composition (Blümmel et al., 1999).

\section{Statistical Analysis}

Statistical analyses were carried out by using SAS software (Version 9.4 for Windows, SAS Institute Inc., Cary, NC).

Data for HP, WI, DMI, fermentative $\mathrm{CO}_{2}$, standing time, and activity counts (240 data sets) were evaluated as 24-h means. Differences in the variables (WI, DMI, MBW, BCS, HP, $\mathrm{CO}_{2}$, standing-lying-quotient, activity counts, fatty acids, $\mathrm{BHB}$, and fermentative $\mathrm{CO}_{2}$ ) between various periods (wk 4 ap and wk 2 pp) were analyzed by one-way repeated measurement ANOVA with the MIXED procedure and a model with the fixed effect.

Differences between EBhp and EBest calculated according to GfE, INRA, or NRC equations were tested by one-way repeated measurement ANOVA with the MIXED procedure. Least squares means and their standard error were calculated and pairwise tested for each effect in each model by using the Tukey-Kramer procedure for pairwise multiple comparisons.

Pearson correlation coefficients for linear regression between EBhp and all variables mentioned above and parameters for milk production (milk yield, ECM, milk fat, milk protein, and milk lactose) were calculated and tested by using the CORR procedure of the Base SAS software. Effects and differences were considered as significant if $P<0.05$.

\section{RESULTS AND DISCUSSION}

Our results with regard to EBest and EBhp of highyielding dairy cows at wk 4 ap and $2 \mathrm{pp}$ are summarized in Figure 1 and Table 2. We found that EBhp was balanced $(2.74 \pm 4.09 \mathrm{MJ}$ of ME/d) in pregnant dry cows but strongly negative $(-84.7 \pm 7.48 \mathrm{MJ}$ of $\mathrm{ME} / \mathrm{d})$ in early-lactating animals. The comparison between EBhp and EBest (GfE, INRA, and NRC) revealed significant differences during both the ap (33 $\mathrm{MJ}$ of $\mathrm{ME} / \mathrm{d}$ ) and pp (67 MJ of ME/d) periods, clearly indicating that actual energy intake was lower or energy requirements were higher than predicted (Table 2). Our data showed that the GfE (2001), NRC (2001), and INRA (2007) equations significantly overestimated $\mathrm{EB}(37 \pm 6,31$ \pm 6 , and $38 \pm 6 \mathrm{MJ}$ of $\mathrm{ME} / \mathrm{d}$ ) of ap cows and underestimated NEB $(-16 \pm 6,-22 \pm 6$, and $-16 \pm 6 \mathrm{MJ}$ of $\mathrm{ME} / \mathrm{d}$ ) of pp cows when compared with the EBhp determined via indirect calorimetric measurements (Figure 1). Equations used to estimate EB for pregnant or lactating cows included the variables MEI and MEm plus the requirements for productive functions, namely the support of gestation or the energy in milk (Agnew et al., 2003; Gruber et al., 2008). In accord with an underestimation of the energy needs, DMI of pregnant cows $(11.1 \pm 0.6 \mathrm{~kg} / \mathrm{d}$; Table 3$)$ was higher than required according to GfE (2001) recommendations $(8.4 \mathrm{~kg} / \mathrm{d})$. On an energy basis, the bias between mean actual energy intake (108 MJ of ME/d) and predicted MEI (82 MJ of ME/d; according to GfE, 2001) amounted to $26 \mathrm{MJ}$ of $\mathrm{ME} / \mathrm{d}$. As expected, the DMI increase (17.5 vs. 28.2 $\mathrm{kg} / \mathrm{d}$, according to GfE recommendations) observed after the onset of lactation (Table 3) was not sufficient to compensate for the high loss of energy via milk (148 $\pm 5 \mathrm{MJ} / \mathrm{d}$ ), resulting in marked catabolism of body fat as reflected by increased blood fatty acid concentrations (by $267 \pm 36 \%$ ). Body reserves (mainly body fat and, to a lesser extent, body protein) are an important fuel supply to assist the cow in reaching her genetic potential for milk synthesis despite NEB (Drackley et al., 2003; Coffey et al., 2004; Weber et al., 2013). In accord, fatty acid concentrations, ECM, milk lactose, and, more strongly, the percentage of milk fat were found to be negatively correlated with early pp EBhp (Table 4). Surprisingly, a noticeable negative correlation between EBhp and fatty acid plasma concentrations was also found during the ap period (Table 4) when EBhp was balanced $(2.74 \pm 4.09 \mathrm{MJ}$ of $\mathrm{ME} / \mathrm{d})$. Under conditions of positive EB, acyl ghrelin plasma concentration of ruminants fluctuates in response to the nutritional state (Wertz-Lutz et al., 2006; Gregorini et al., 2009). Indeed, using values measured in another part of our joint project (Börner et al., 2013b), we found a strong negative correlation between the ap EBhp and acyl ghrelin plasma concentrations $(\mathrm{r}=-0.64, P<0.01)$. Acyl ghrelin has been shown to have lipolytic effects in muscle tissue (Barazzoni et al., 2005; Vestergaard et al., 2011) and to increase fatty acid concentrations in cows (ThidarMyint et al., 2006; Roche et al., 2008). Changes in acyl ghrelin plasma concentration could therefore explain the observed link between EBhp and lipolysis in ap cows. The expected positive correlation between EBhp and DMI was observed in pregnant cows only (Table 4). In contrast, EBhp of early-lactating cows 


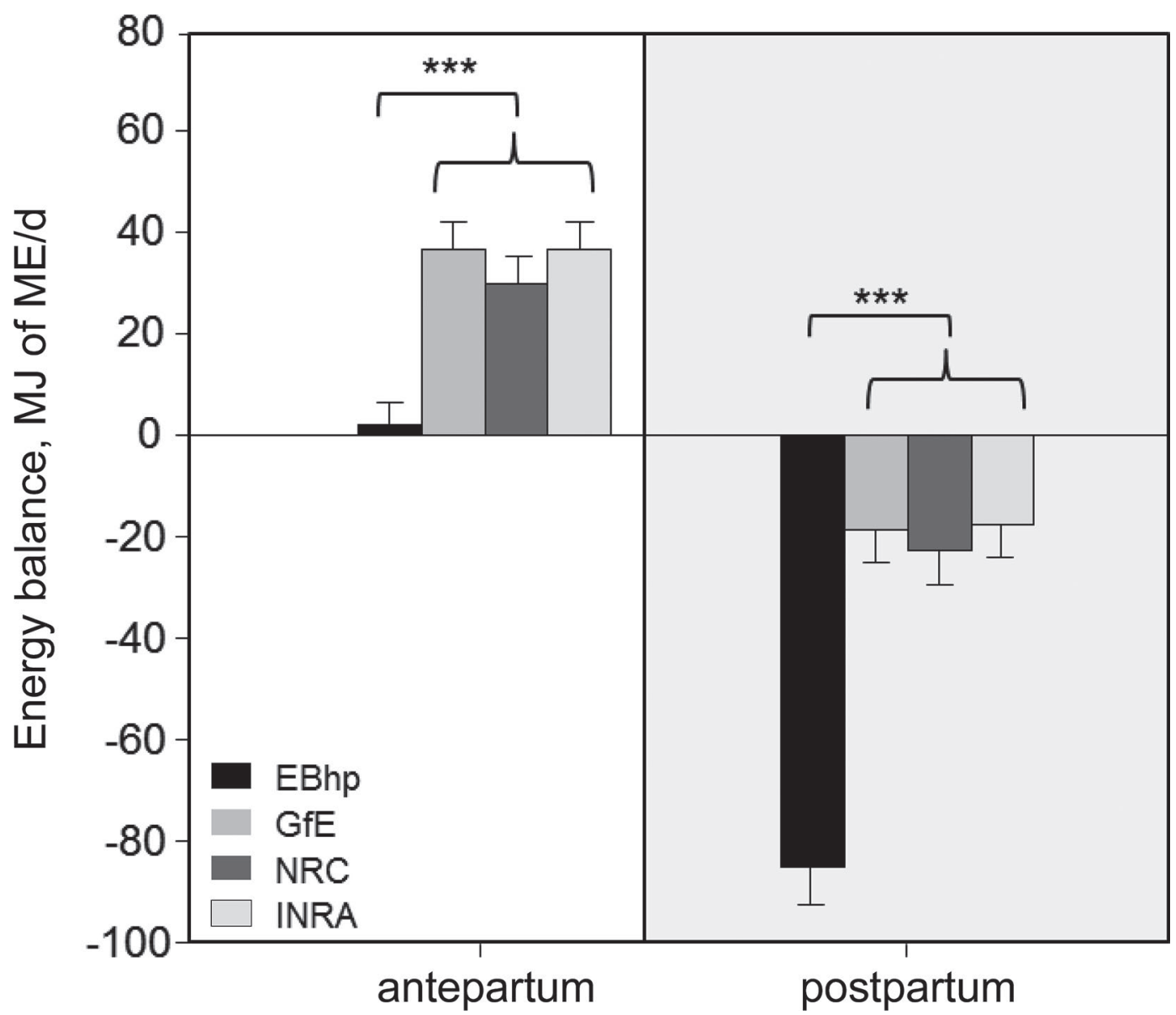

Figure 1. Antepartum and postpartum energy balance (LSM $\pm \mathrm{SE}$ ) of high-yielding German Holstein cows as estimated using common equations published by the German Society for Nutrition Physiology (GfE), the French National Institute for Agricultural Research (INRA), and NRC or the calorimetrically measured heat production (EBhp). ${ }^{* * *} P<0.001$.

was highly related to ECM and percentage of milk fat, but not to DMI (Table 4). A possible explanation for this result is given by ample data showing that highyielding dairy cows, specifically during early lactation, partition a higher proportion of MEI and of nutrients arising from body reserve mobilization into milk and less into body tissue (Agnew and Yan, 2000; Yan et al., 2006). Interestingly, portal and hepatic blood flows, main determinants of splanchnic tissues metabolism, have also been shown to be better related to milk yield

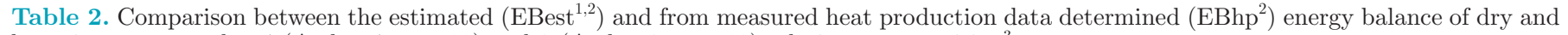
lactating cows at $\mathrm{wk}-4(\Delta \mathrm{wk}-4 ; \mathrm{n}=18)$ and $2(\Delta \mathrm{wk}+2 ; \mathrm{n}=19)$ relative to parturition ${ }^{3}$

\begin{tabular}{llccr}
\hline Parameter & Unit & $\Delta$ wk -4 & $P$-value & $\Delta$ wk +2 \\
\hline EB (GfE) - (EBhp) & MJ of ME/d & $34.7 \pm 5.75$ & $<0.001$ & $68.6 \pm 8.05$ \\
EB (NRC)-(EBhp) & MJ of ME/d & $28.2 \pm 5.72$ & $<0.001$ & $62.4 \pm 8.07$ \\
EB (INRA) - (EBhp) & MJ of ME/d & $35.0 \pm 5.75$ & $<0.001$ & $68.9 \pm 8.05$ \\
\hline
\end{tabular}

${ }^{1}$ EBest was calculated according to equations published by the German Society of Nutrition Physiology $(2001)=\mathrm{EB}(\mathrm{GfE})$; the NRC $(2001)=$ EB (NRC); and the Institut National de la Recherche Agronomique (2007) = EB (INRA).

${ }^{2}$ For both EBhp and EBest of individual cows, ME intake has been calculated based on the measured individual feed intake, the DM and nutrient contents, and in vitro enzyme-soluble organic substance (ELOS) of the respective diets. The DM and nutrient contents and ELOS were analyzed following procedures described in VDLUFA (1993). Dietary ME concentration was then estimated from analyzed crude nutrient amounts and ELOS as: $9.67-0.01698 \times$ crude ash $+0.00340 \times \mathrm{CP}+0.01126 \times$ crude fat $+0.00123 \times$ starch $-0.00097 \times \mathrm{NDF}$ on an OM basis +0.00360 $\times$ ELOS (Pries et al., 2009; GfE, 2009).

${ }^{3}$ The difference between EBest and EBhp $(\Delta)$ has been calculated and data are given as LSM \pm SE. A $P$-value of $<0.05$ is considered to reflect significant differences between EBest and EBhp during the respective period. 
Table 3. Water intake (WI), DMI, metabolic BW (MBW), BCS, heat production (HP), physical activity, standing-lying quotient, fatty acids, BHB, fermentative $\mathrm{CO}_{2}\left[\mathrm{CO}_{2}(\right.$ ferm $\left.)\right]$, milk yield, ECM, and milk components of dry and lactating cows at wk $-4(\mathrm{wk}-4 ; \mathrm{n}=18)$ and $2(\mathrm{wk}+2 ; \mathrm{n}=19)$ relative to parturition ${ }^{1}$

\begin{tabular}{|c|c|c|c|}
\hline Parameter & wk -4 & $\mathrm{wk}+2$ & $\begin{array}{c}P \text {-value } \\
(\text { wk }-4 \text { vs. wk }+2)\end{array}$ \\
\hline WI, L/d & $29.9 \pm 2.64$ & $73.4 \pm 2.59$ & $<0.001$ \\
\hline DMI, $\mathrm{kg} / \mathrm{d}$ & $11.1 \pm 0.61$ & $17.5 \pm 0.57$ & $<0.001$ \\
\hline MBW. $\mathrm{kg}^{0.75}$ & $140 \pm 1.80$ & $135 \pm 2.10$ & 0.001 \\
\hline $\mathrm{BCS}$ & $3.26 \pm 0.15$ & $2.79 \pm 0.17$ & $<0.01$ \\
\hline $\mathrm{HP}, \mathrm{kJ} / \mathrm{kg}^{0.75}$ per day & $762 \pm 24.9$ & $1,024 \pm 20.1$ & $<0.001$ \\
\hline Physical activity, movements/h & $11,170 \pm 1,128$ & $13,705 \pm 1,119$ & 0.06 \\
\hline Standing time/lying time & $1.94 \pm 0.40$ & $2.01 \pm 0.25$ & NS \\
\hline Fatty acids, $\mu \mathrm{mol} / \mathrm{L}$ & $171 \pm 21.6$ & $511 \pm 33.1$ & $<0.001$ \\
\hline $\mathrm{BHB}, \mathrm{mmol} / \mathrm{L}$ & $0.43 \pm 0.02$ & $0.88 \pm 0.13$ & $<0.01$ \\
\hline $\mathrm{CO}_{2}($ ferm $),{ }^{2} \mathrm{~L} / \mathrm{h}$ & $2.34 \pm 0.11$ & $3.39 \pm 0.08$ & $<0.001$ \\
\hline Milk yield, $\mathrm{kg} / \mathrm{d}$ & & $40.41 \pm 1.32$ & \\
\hline $\mathrm{ECM}, \mathrm{kg} / \mathrm{d}$ & & $47.2 \pm 1.51$ & \\
\hline Milk fat, $\%$ & & $5.29 \pm 0.19$ & \\
\hline Milk protein, $\%$ & & $3.53 \pm 0.06$ & \\
\hline Milk lactose, \% & & $4.74 \pm 0.03$ & \\
\hline
\end{tabular}

${ }^{1}$ Data are given as LSM $\pm \mathrm{SE}$ and a $P$-value of $<0.05$ is considered significant.

${ }^{2} \mathrm{CO}_{2}$ (ferm) reflects rumen fermentative activity and has been calculated according to Chwalibog et al. (1996).

than to MEI in early-lactating cows (Durand et al., 1992).

For both EBhp and EBest, MEI has been calculated based on the measured individual feed intake of the cows and on the DM, nutrient, and in vitro ELOS (Pries et al., 2009) contents of the respective diets as described in the Materials and Methods section. In addition, the milk energy of lactating cows has been calculated in the same way for EBhp and EBest using the equation published by Reist et al. (2002), considering measured milk yield and values for milk fat, protein, and lactose. Thus, possible inaccuracies in the calculation of energy in consumed feeds and in produced milk will equally af- fect the values for EBhp and EBest and cannot explain the observed differences between them. Therefore, we considered that the factors (0.488 to 0.534 MJ of ME) currently used to calculate MEm (factor $\times$ MBW) for dairy cows most probably underestimate the animal's needs.

Our assumption is supported by various studies (Yan et al., 1997a,b; Kebreab et al., 2003; Gruber et al., 2008) showing that MEm values taken from data of respiratory trials are constantly higher than those predicted by energy feeding systems. Using equations given by the AFRC (1993), GfE (2001), NRC (2001), and INRA (2007), Gruber et al. (2008) calculated a

Table 4. Correlations between the energy balance calculated from heat production data obtained by respiratory trials (EBhp) and parameters of energy status, physical activity, and metabolism for cows at wk -4 (wk -4 ; $\mathrm{n}=18)$ and $2(\mathrm{wk}+2 ; \mathrm{n}=19)$ relative to parturition ${ }^{1}$

\begin{tabular}{|c|c|c|c|c|}
\hline Parameter $^{2}$ & wk -4 & $P$-value & $\mathrm{wk}+2$ & $P$-value \\
\hline WI, L/d & 0.23 & 0.357 & -0.20 & 0.40 \\
\hline DMI, kg/d & 0.80 & $<0.001$ & 0.38 & 0.11 \\
\hline MBW, $\mathrm{kg}^{0.75}$ & 0.03 & 0.89 & -0.70 & $<0.001$ \\
\hline $\mathrm{BCS}$ & -0.43 & 0.07 & -0.24 & 0.33 \\
\hline $\mathrm{HP}, \mathrm{kJ} / \mathrm{kg}^{0.75}$ per day & 0.18 & 0.47 & -0.40 & 0.09 \\
\hline Physical activity, movements/h & 0.34 & 0.17 & -0.21 & 0.38 \\
\hline Standing time/lying time & -0.14 & 0.57 & -0.31 & 0.19 \\
\hline Fatty acids, $\mu \mathrm{mol} / \mathrm{L}$ & -0.60 & $<0.01$ & -0.50 & 0.04 \\
\hline $\mathrm{BHB}, \mathrm{mmol} / \mathrm{L}$ & 0.13 & 0.62 & 0.03 & 0.90 \\
\hline $\mathrm{CO}_{2}($ ferm $), \mathrm{L} / \mathrm{h}$ & 0.53 & 0.02 & 0.40 & 0.09 \\
\hline Milk yield, $\mathrm{kg} / \mathrm{d}$ & & & -0.11 & 0.66 \\
\hline $\mathrm{ECM}, \mathrm{kg} / \mathrm{d}$ & & & -0.60 & $<0.01$ \\
\hline Milk fat, $\%$ & & & -0.73 & $<0.001$ \\
\hline Milk protein, \% & & & -0.08 & 0.73 \\
\hline Milk lactose, \% & & & 0.52 & 0.02 \\
\hline
\end{tabular}

${ }^{1}$ Pearson cross-correlation coefficients are given and a $P$-value of $<0.05$ is considered significant and set in bold. ${ }^{2} \mathrm{WI}=$ water intake; $\mathrm{MBW}=$ metabolic body weight; $\mathrm{HP}=$ heat production; $\mathrm{CO}_{2}($ ferm $)=$ fermentative $\mathrm{CO}_{2}$, which reflects rumen fermentative activity and has been calculated according to Chwalibog et al. (1996). 
mean MEm of $0.507 \mathrm{MJ}$ of $\mathrm{ME} / \mathrm{kg}$ of $\mathrm{MBW}$, which underestimates current needs by $22 \%$. Employing data from the respiratory trials of our study, we calculated $\mathrm{HP}$ values of $0.76 \pm 0.02$ and $1.02 \pm 0.02 \mathrm{MJ}$ of ME/ $\mathrm{kg}^{0.75}$ for cows at wk 4 ap and $2 \mathrm{pp}$, respectively. Although measured under standard conditions of thermoneutrality and locomotion restriction, these HP values are 19 and 59\% higher, respectively, than the factors published by Agnew and Yan (2000), Gruber et al. (2008), and Susenbeth (2018), who reported values between 0.62 to $0.65 \mathrm{MJ}$ of $\mathrm{ME} / \mathrm{kg}^{0.75}$. For nonlactating cows, the difference between these factors and the HP value of our study might result from the fact that the energy requirement for gravidity (uterus and udder) is included in the latter. Data from feeding trials were analyzed by Gruber et al. (2008) and reveal significant effects of energy balance, live weight changes, and lactation stage on regression coefficients for MEm, milk energy output, and tissue mobilization or gain. Interestingly, the regression coefficients for MEm were $>1 \mathrm{MJ}$ of $\mathrm{ME} / \mathrm{kg}^{0.75}$ during the first month of lactation and $0.828 \mathrm{MJ}$ of $\mathrm{ME} / \mathrm{kg}^{0.75}$ in midlactation, which is in good agreement with the HP measured in our current experiment.

In our trials, the calculation of EBhp was based on measured HP, which included heat released through basal metabolism, the thermic effect of feed, physical activity, thermoregulation, the processes related to tissue gain and catabolism, and milk synthesis or secretion. Compared with dry periods, a $26 \%$ increase in HP has been observed in lactating dairy cows (Agnew and Yan, 2000; Jentsch et al., 2001; Agnew et al., 2003). In our study, after the onset of lactation, HP increased by $36 \pm 4 \%$, mainly because of milk production and increased $(64 \pm 7 \%)$ feed intake (Table 3). Adaptation to an energy-rich, high-carbohydrate lactation diet includes the elevation of absorption and intraepithelial breakdown of short-chain fatty acids, mainly (95\%) of n-butyrate (summarized in Gäbel et al., 2002). Therefore, elevated BHB concentrations $(104 \pm 23 \%)$ found in blood plasma of lactating cows do not only reflect ketogenic effects of fat mobilization, but result mainly from intraepithelial transformation of butyrate into BHB (Kristensen et al., 2000). The BHB released by the ruminal epithelium is able to bypass the liver and has a glucose-sparing effect by acting as an important energy source for extrahepatic tissues (e.g., striated muscle, adipose tissue, kidney, and intestinal mucosal cells; Robinson and Williamson, 1980). In accord, observed BHB values (Table 3) were below threshold concentrations for subclinical $(1.0 \mathrm{mmol} / \mathrm{L})$ or clinical $(3.0 \mathrm{mmol} / \mathrm{L})$ ketosis in cows at wk 4 ap and $2 \mathrm{pp}$, respectively.
The HP in muscle comprises processes related to intermediary metabolism, but in vivo they can be relatively minor compared with thermogenesis due to postural status (standing or lying position) and other physical muscle activity (Lobley, 1990). In out trial, cows spent more time standing than lying at both time points investigated, and no difference in standing time was observed between dry and lactating cows (Table 3). In addition, other physical activity (movements) was similar before and after calving, although we noticed a trend for increased activity $(P=0.06)$ in lactating cows. This added physical activity increases the energy expended (Clark et al., 1972; Lobley, 1990) and can be partly responsible for the greater discrepancy between EBest and EBhp in lactating cows. We also investigated the response to a 10-h fasting challenge in cows at wk 4 ap (Erdmann et al., 2018). The cows lowered general physical activity (33\%) and standing duration (40\%), thereby reducing activity-related $\mathrm{HP}$ as an effective behavioral adaptation to feed deprivation. Contrary to these results, but in accord with current data, steers (Derno et al., 2005) and calves (Schrama et al., 1995) spend more time standing during energy restriction.

Equations used to predict EB consider maintenance requirements $(\mathrm{EB}=0)$ that were classically determined under confined conditions in cows that had a maintenance feeding level, were not pregnant or lactating, and were fully grown (GfE, 2001). This is, however, similar to basal metabolism, which depends on body size or weight and composition (Hoffman, 1997; Agnew et al., 2003). Thus, a higher protein content in the body (Agnew and Yan, 2000) and the selection for increased body dimensions and high ad libitum feed intake (Hansen et al., 1999; Hansen, 2000), accompanied by an increased size, proportion of BW, and activity of inner organs needed for digestion, metabolism, and blood circulation (Johnson et al., 1990; Taylor and Murray, 1991; Reynolds, 1996), might all contribute to the general elevation of MEm in high-yielding dairy cow breeds (Gruber et al., 2008). Effects of body dimensions or BW will be more pronounced in early lactation, when larger cows with higher MBW, and thus higher maintenance requirements (Hansen, 2000; Hofstetter et al., 2011), will experience a greater gap between the needed and consumed energy, as the latter is mainly used to support milk yield (Reist et al., 2002; Coffey et al., 2004; García et al., 2011). In accord, our study revealed a strong negative correlation between EBhp and MBW in early-lactating cows (Table 4).

In addition, the proportion of metabolically highly active organs (Huntington, 1990) increases in lactating cows because carcass fat, and to a lesser extent muscle mass, is reduced (Börner et al., 2013a; Schäff et al., 
2013) and the mammary gland (Dessauge et al., 2011), liver, and gastrointestinal tract masses increase continuously during early lactation (Johnson et al., 1990). Moreover, AA have been shown to be partitioned into the liver and increase its protein content (Schäff et al., 2012). The MBW declined only slightly, by $4 \pm 1 \%$, in the early-lactating cows of our study, whereas their BCS decreased by $13 \pm 4 \%$ due to increased rates of fat mobilization (Tamminga et al., 1997; Hammon et al., 2009). In cows lacking sufficient reserves of mobilizable body fat (under-conditioned cows), a higher proportion of their energy supply may be met by the energetically expensive process of body protein catabolism (Chowdhury and Ørskov, 1994; Birnie et al., 2000). Thus, cows with low BCS might display a proportional higher HP (per $\mathrm{kg}^{0.75}$ ) compared with cows of optimal condition (Birnie et al., 2000). Indeed, a negative correlation between BCS and HP $(\mathrm{r}=-0.484 ; P=0.0418)$ has been found, but only at wk 4 ap.

\section{CONCLUSIONS}

Energy balance of high-yielding dairy cows calculated by use of measured HP data differs significantly from EBest at wk 4 ap and 2 pp, with a higher deviation postpartum. Because similar MEI and milk energy values were used for calculation of EBest and EBhp, we suggest that observed differences are mainly related to higher than predicted MEm values. The DMI and plasma fatty acid concentration show the strongest correlation with EBhp of dry, pregnant cows, whereas MBW and milk fat content are closely related to EBhp of early-lactating cows. Regulation of mobilization and partition of body reserves (protein and fat) is of importance. Further experimental work with dairy cows whose milk production is $>10,000 \mathrm{~kg}$ has to be performed to create the extensive database needed to optimize and eventually standardize the models and equations used to predict the energy requirements of these animals. In addition, the observed differences between EBhp and EBest must be taken into account when experimental data are interpreted, because EBest has been used in most studies and the true energy status might be overestimated.

\section{ACKNOWLEDGMENTS}

We thank the staff at the Experimental Cattle Facility of the FBN (Bernd Stabenow and co-workers) and the staff of the Institute of Nutritional Physiology "Oskar Kellner" at the FBN Tiertechnikum (Dirk Oswald, Astrid Schulz, Kerstin Pilz, Roland Gaeth, and Kerstin Korinth) for assistance with animal care. We further acknowledge the help of the Cattle Breeding Organization Mecklenburg-West Pommerania (Rinder Allianz GmbH, Woldegk, Germany) and the Griepentrog farm (Steinhagen, Germany) for the assortment of cows. In addition, the authors express their gratitude to T. Jones (Scientific Linguistic Assistance, R.T. Jones, Wolfenbüttel, Germany) for linguistic corrections. The authors declare no conflict of interest that could be perceived as prejudicing the impartiality of the research reported. This study was supported by the Deutsche Forschungsgemeinschaft (DFG, Bonn, Germany; SCHW $642 / 7-1$ ). The publication of this article was funded by the Open Access Fund of the Leibniz Institute for Farm Animal Biology (FBN). This research did not receive any grants from the commercial sector.

\section{REFERENCES}

AFRC (Agricultural Food and Research Council). 1993. Energy and Protein Requirements of Ruminants. An Advisory Manual Prepared by the AFRC Technical Committee on Responses to Nutrients. CAB International, Wallingford, UK.

Agnew, R. E., and T. Yan. 2000. The impact of recent research on energy feeding systems for dairy cattle. Livest. Prod. Sci. 66:197-215.

Agnew, R. E., T. Yan, J. J. Murphy, C. P. Ferris, and F. J. Gordon. 2003. Development of maintenance energy requirement and energetic efficiency for lactation from production data of dairy cows. Livest. Prod. Sci. 82:151-162.

Barazzoni, R., A. Bosutti, M. Stebel, M. R. Cattin, E. Roder, L. Visintin, L. Cattin, G. Biolo, M. Zanetti, and G. Guarnieri. 2005. Ghrelin regulates mitochondrial-lipid metabolism gene expression and tissue fat distribution in liver and skeletal muscle. Am. J. Physiol. Endocrinol. Metab. 288:E228-E235.

Birnie, J. W., R. E. Agnew, and F. J. Gordon. 2000. The influence of body condition on the fasting energy metabolism of nonpregnant, nonlactating dairy cows. J. Dairy Sci. 83:1217-1223.

Blümmel, M., K. P. Aiple, H. Steingaß, and K. Becker. 1999. A note on the stoichiometrical relationship of short chain fatty acid production and gas formation in vitro in feedstuffs of widely differing quality. J. Anim. Physiol. Anim. Nutr. (Berl.) 81:157-167.

Börner, S., E. Albrecht, C. Schäff, S. Hacke, and U. Kautzsch., MDerno, H. M., M. Hammon, H. Röntgen, Sauerwein, and B. Kuhla. 2013a. Reduced AgRP activation in the hypothalamus of cows with high extent of fat mobilization after parturition. Gen. Comp. Endocrinol. 193:167-177.

Börner, S., M. Derno, S. Hacke, U. Kautzsch, C. Schäff, S. T. Than, H. Kuwayama, H. M. Hammon, M. Röntgen, R. Weikard, C. Kühn, A. Tuchscherer, and B. Kuhla. 2013b. Plasma ghrelin is positively associated with body fat, liver fat and milk fat content but not with feed intake of dairy cows after parturition. J. Endocrinol. 216:217-229.

Brouwer, E. 1965. Report of sub-committee on constants and factors. Pages 441-443 in Proceedings of the 3rd Symposium on Energy Metabolism, no. 11 K. L. Blaxter, ed. EAAP, Troon, UK.

Butler, W. R. 2000. Nutritional interactions with reproductive performance in dairy cattle. Anim. Reprod. Sci. 60-61:449-457.

Chilliard, Y., F. Bocquier, and M. Doreau. 1998. Digestive and metabolic adaptations of ruminants to undernutrition, and consequences on reproduction. Reprod. Nutr. Dev. 38:131-152.

Chowdhury, S. A., and E. R. Ørskov. 1994. Implications of fasting on the energy metabolism and feed evaluation in ruminants. J. Anim. Feed Sci. 3:161-169.

Chwalibog, A., K. Jensen, and G. Thorbek. 1996. Oxidation of nutrients in bull calves treated with beta-adrenergic agonists. Arch. Tierenahr. 49:255-261. 
Clark, R. M., J. B. Holter, N. F. Colovos, and H. H. Haye. 1972. Effect of postural position and position changes on energy expenditure in fasting dairy cattle. J. Dairy Sci. 55:257-260.

Coffey, M. P., G. Simm, J. D. Oldham, W. G. Hill, and S. Brotherstone. 2004. Genotype and diet effects on energy balance in the first three lactations of dairy cows. J. Dairy Sci. 87:4318-4326.

Collard, B. L., P. J. Boettcher, J. C. Dekkers, D. Petitclerc, and L. R. Schaeffer. 2000. Relationships between energy balance and health traits of dairy cattle in early lactation. J. Dairy Sci. 83:2683-2690.

de Vries, M. J., and R. F. Veerkamp. 2000. Energy balance of dairy cattle in relation to milk production variables and fertility. J. Dairy Sci. 83:62-69.

Derno, M., H. G. Elsner, E. A. Paetow, H. Scholze, and M. Schweigel. 2009. Technical note: A new facility for continuous respiration measurements in lactating cows. J. Dairy Sci. 92:2804-2808.

Derno, M., W. Jentsch, M. Schweigel, S. Kuhla, C. C. Metges, and H. D. Matthes. 2005. Measurements of heat production for estimation of maintenance energy requirements of Hereford steers. J. Anim. Sci. 83:2590-2597.

Derno, M., G. Nürnberg, P. Schön, A. Schwarm, M. Röntgen, H. M Hammon, C. C. Metges, R. M. Bruckmaier, and B. Kuhla. 2013 Short-term feed intake is regulated by macronutrient oxidation in lactating Holstein cows. J. Dairy Sci. 96:971-980.

Dessauge, F., V. Lollivier, B. Ponchon, R. Bruckmaier, L. Finot, S. Wiart, E. Cutullic, C. Disenhaus, S. Barbey, and M. Boutinaud. 2011. Effects of nutrient restriction on mammary cell turnover and mammary gland remodeling in lactating dairy cows. J. Dairy Sci. 94:4623-4635

Dijkstra, J., O. Oenema, J. W. van Groningen, J. W. Spek, A. M. van Vuuren, and A. Bannink. 2013. Diet effects on urine composition of cattle and N2O emissions. Animal 7(Suppl. 2):292-302.

Drackley, J. K. 2002. Transition cow management and periparturient metabolic disorders. Pages 224-233 in Recent Developments and Perspectives in Bovine Medicines Keynote Lectures. M. Kaske, H. Scholz, and M. Höltershinken, ed. Hildesheimer Druck-und Verlags $\mathrm{GmbH}$, Hannover, Germany.

Drackley, J. K., T. M. Cicela, and D. W. LaCount. 2003. Responses of primiparous and multiparous Holstein cows to additional energy from fat or concentrate during summer. J. Dairy Sci. 86:1306-1314.

Durand, D., J. Lefaivre, Y. Chilliard, and D. Bauchart. 1992. Effects of food intake and milk yield on portal and hepatic vein blood flow of high yielding dairy cows in early lactation. Reprod. Nutr. Dev. 32:505.

Edmonson, A. J., I. J. Lean, L. D. Weaver, T. Farver, and G. Webster. 1989. A body condition scoring chart for Holstein dairy cows. J. Dairy Sci. 72:68-78.

Erdmann, S., E. Mohr, M. Derno, A. Tuchscherer, C. Schäff, S. Börner, U. Kautzsch, B. Kuhla, H. M. Hammon, and M. Röntgen. 2018. Indices of heart rate variability as potential early markers of metabolic stress and compromised regulatory capacity in dried-of high-yielding dairy cows. Animal 12:1451-1461. https://doi.org/10 $.1017 /$ S1751731117002725.

Gäbel, G., J. R. Aschenbach, and F. Müller. 2002. Transfer of energy substrates across the ruminal epithelium: Implications and limitations. Anim. Health Res. Rev. 3:15-30.

García, A. M. B., F. C. Cardoso, R. Campos, D. X. Thedy, and F. H. D. González. 2011. Metabolic evaluation of dairy cows submitted to three different strategies to decrease the effects of negative energy balance in early postpartum. Pesqui. Vet. Bras. 31:11-17.

GfE (German Society of Nutrition Physiology). 1997. Mitteilungen des Ausschusses für Bedarfsnormen der Gesellschaft für Ernährungsphysiologie. Zum Proteinbedarf von Milchkühen und Aufzuchtrindern. 6:217-236.

GfE (German Society of Nutrition Physiology). 2001. Recommended Energy and Nutrient Supply for Dairy Cows and Growing Cattle. 8 ed. GfE, Frankfurt am Main, Germany.

GfE (Society of Nutrition Physiology). 2009. New equations for predicting metabolisable energy of compound feeds for cattle. Proc. Soc. Nutr. Physiol. 18:143-146.

Goff, J. P. 2006. Major advances in our understanding of nutritional influences on bovine health. J. Dairy Sci. 89:1292-1301.
Gregorini, P., K. J. Soder, and R. s. Kensinger. 2009. Effects of rumen fill on short-term ingestive behavior and circulating concentrations of ghrelin, insulin, and glucose of dairy cows foraging vegetative micro-swards. J. Dairy Sci. 92:2095-2105.

Gross, J., H. A. van Dorland, R. M. Bruckmaier, and F. J. Schwarz. 2011. Performance and metabolic profile of dairy cows during a lactational and deliberately induced negative energy balance with subsequent realimentation. J. Dairy Sci. 94:1820-1830.

Gruber, L., A. Susenbeth, F. J. Schwarz, B. Fischer, H. Spiekers, H Steingass, U. Meyer, A. Chassot, T. Jilg, and A. Obermaier. 2008 Bewertung des NEL-Systems und Schätzung des Energiebedarfs von Milchkühen auf der Basis von umfangreichen Fütterungsversuchen in Deutschland, Österreich und der Schweiz. Pages 47-57 in Lehr-und Forschungszentrum für Landwirtschaft RaumbergGumpenstein, Irdning, Germany. https://www.openagrar.de/ receive/fimport_mods_00001643.

Grummer, R. R., D. G. Mashek, and A. Hayirli. 2004. Dry matter intake and energy balance in the transition period. Vet. Clin. North Am. Food Anim. Pract. 20:447-470.

Hammon, H. M., G. Stürmer, F. Schneider, A. Tuchscherer, H. Blum, T. Engelhard, A. Genzel, R. Staufenbiel, and W. Kanitz. 2009. Performance and metabolic and endocrine changes with emphasis on glucose metabolism in high-yielding dairy cows with high and low fat content in liver after calving. J. Dairy Sci. 92:1554-1566.

Hansen, L. B. 2000. Consequences of selection for milk yield from a geneticist's viewpoint. J. Dairy Sci. 83:1145-1150.

Hansen, L. B., J. B. Cole, G. D. Marx, and A. J. Seykora. 1999. Productive life and reasons for disposal of Holstein cows selected for large versus small body size. J. Dairy Sci. 82:795-801.

Harrison, R. O., S. P. Ford, J. W. Young, and A. E. Freeman. 1990. Increased milk production versus reproductive and energy status of high producing dairy cows. J. Dairy Sci. 73:2749-2758.

Heuer, C., Y. H. Schukken, and P. Dobbelaar. 1999. Postpartum body condition score and results from the first test day milk as predictors of disease, fertility, yield, and culling in commercial dairy herds. J. Dairy Sci. 82:295-304.

Hoffman, P. C. 1997. Optimum body size of Holstein replacement heifers. J. Anim. Sci. 75:836-845.

Hofstetter, P., M. Steiger Burgos, R. Petermann, A. Münger, J. W. Blum, P. Thomet, H. Menzi, S. Kohler, and P. Kunz. 2011. Does body size of dairy cows, at constant ratio of maintenance to production requirements, affect productivity in a pasture-based production system? J. Anim. Physiol. Anim. Nutr. (Berl.) 95:717-729. https://doi.org/10.1111/j.1439-0396.2010.01102.x.

Huntington, G. B. 1990. Energy metabolism in the digestive tract and liver of cattle: influence of physiological state and nutrition. Reprod. Nutr. Dev. 30:35-47.

INRA (Institut National de la Recherche Agronomique). 2007. Alimentation des bovins, ovins et caprins. besoins des animaux-Valeurs des Aliments. Tables INRA 2007. Editions Quae, c/o INRA, Versailles, France.

Jentsch, W., M. Derno, and O. Weiher. 2001. Wärmeabgabe der Milchkühe in Abhängigkeit von der Leistung - eine Studie. Arch. Anim. Breed. 44:599-610.

Johnson, D. E., K. A. Johnson, and R. L. Baldwin. 1990. Changes in liver and gastrointestinal tract energy demands in response to physiological workload in ruminants. J. Nutr. 120:649-655.

Kebreab, E., J. France, R. E. Agnew, T. Yan, M. S. Dhanoa, J. Dijkstra, D. E. Beever, and C. K. Reynolds. 2003. Alternatives to linear analysis of energy balance data from lactating dairy cows. J. Dairy Sci. 86:2904-2913.

Kristensen, N. B., S. G. Pierzynowski, and A. Danfaer. 2000. Portaldrained visceral metabolism of 3-hydroxybutyrate in sheep. J. Anim. Sci. 78:2223-2228.

LeBlanc, S. J., K. D. Lissemore, D. F. Kelton, T. F. Duffield, and K. E. Leslie. 2006. Major advances in disease prevention in dairy cattle. J. Dairy Sci. 89:1267-1279.

Lobley, G. E. 1990. Energy metabolism reactions in ruminant muscle: Responses to age, nutrition and hormonal status. Reprod. Nutr. Dev. 30:13-34. 
Lopez, H., L. D. Satter, and M. C. Wiltbank. 2004. Relationship between level of milk production and estrous behavior of lactating dairy cows. Anim. Reprod. Sci. 81:209-223.

Melesse, A. 2012. In vitro evaluation of utilizable crude protein using ruminal fluid in leaves, whole and seeds-removed pods of Moringa stenopetala and Moringa oleifera grown in the rift valley of Ethiopia. Ethiop. J. Agric. Sci. 22:62-72.

Moe, P. W., W. P. Flatt, and H. F. Tyrrell. 1972. The net energy values of feeds for lactation. J. Dairy Sci. 55:945-958.

Murphy, D. G., S. M. Waters, S. D. McCarthy, J. Patton, B. Early, R. Fitzpatrick, J. J. Murphy, M. G. Diskin, D. A. Kenny, A. Brass, and D. C. Wathes. 2009. Pleiothrophic effects of negative energy balance in the postpartum dairy cow on splenic gene expression: Repercussions for innate and adaptive immunity. Physiol. Genomics 39:28-37.

NRC (National Research Council). 2001. Nutrient Requirements of Dairy Cattle. 7th rev. ed. Natl. Acad. Press, Washington, DC.

Pries, M., A. Menke, E. Tholen, and K.-H. Südekum. 2009. Neue Gleichungen zur Schätzung der umsetzbaren Energie von Mischfutter für Rinder. https://www.dlg.org/fileadmin/downloads/fachinfos/ futtermittel/Schaetzgleichungen_Rind_Mischfutter_2009.pdf.

Rastani, R. R., S. M. Andrew, S. A. Zinn, and C. J. Sniffen. 2001. Body composition and estimated tissue energy balance in Jersey and Holstein cows during early lactation. J. Dairy Sci. 84:12011209.

Reist, M., D. Erdin, D. von Euw, K. Tschuemperlin, H. Leuenberger, Y. Chilliard, H. M. Hammon, C. Morel, C. Philipona, Y. Zbinden, N. Kuenzi, and J. W. Blum. 2002. Estimation of energy balance at the individual and herd level using blood and milk traits in highyielding dairy cows. J. Dairy Sci. 85:3314-3327.

Reynolds, C. K. 1996. Nutritional requirements of the high genetic merit dairy cow: Constraints of feeding grasses and legumes. Pages $7-15$ in Grass and Forage for Cattle of High Genetic Merit. British Grassland Society, Great Malvern, UK.

Robinson, A. M., and D. H. Williamson. 1980. Physiological roles of ketone bodies as substrates and signals in mammalian tissues. Physiol. Rev. 60:143-187.

Roche, J. R., A. J. Sheahan, L. M. Chagas, D. Blache, D. P. Berry, and J. K. Kay. 2008. Long-term infusions of ghrelin and obestatin in early lactation dairy cows. J. Dairy Sci. 91:4728-4740.

Schäff, C., S. Börner, S. Hacke, U. Kautzsch, D. Albrecht, C. Kühn, H. M. Hammon, M. Röntgen, and B. Kuhla. 2012. Increased anaplerosis, TCA cycling and oxidative phosphorylation in the liver of dairy cows with intensive body fat mobilization during early lactation. J. Proteome Res. 11:5503-5514.

Schäff, C., S. Börner, S. Hacke, U. Kautzsch, H. Sauerwein, S. K. Spachmann, M. Schweigel-Röntgen, H. M. Hammon, and B. Kuhla. 2013. Increased muscle fatty acid oxidation in dairy cows with intensive body fat mobilization during early lactation. J. Dairy Sci. 96:6449-6460.

Schiemann, R., K. Nehring, L. Hoffmann, W. Jentsch, and A. Chudy. 1971. Energetische Futterbewertung und Energienormen. VEB Deutscher Landwirtschafts-Verlag, Berlin, Germany.

Schmidt, T., K. Krawielitzki, J. Voigt, and M. Gabel. 2005. Methodical aspect of the in situ technique for estimating ruminal nutrient degradation: microbial contamination and lag time. Übersicht. Tierernährung 33:87-100.

Schrama, J. W., J. P. Roefs, J. Gorssen, M. J. Heetkamp, and M. W. Verstegen. 1995. Alteration of heat production in young calves in relation to posture. J. Anim. Sci. 73:2254-2262.

Susenbeth, A. 2018. Der Energiebedarf von Milchkühen heutiger Rassen. Pages 88-93 in Schriftenreihe der Agrar- und Ernährungswissenschaftlichen Fakultät der Universität Kiel, vol. 125. Selbstverlag der Agrar-und Ernährungswissenschaftlichen Fakultät der Christian-Albrechts-Universität zu Kiel, Kiel, Germany.

Tamminga, S., P. A. Luteijnb, and R. G. M. Meijerc. 1997. Changes in composition and energy content of liveweight loss in dairy cows with time after parturition. Livest. Prod. Sci. 52:31-38.
Taylor, C. S., and J. I. Murray. 1991. Effect of feeding level, breed and milking potential on body tissues and organs of mature, nonlactating cows. Anim. Sci. 53:27-38.

ThidarMyint, H., H. Yoshida, T. Ito, and H. Kuwayama. 2006. Dosedependent response of plasma ghrelin and growth hormone concentrations to bovine ghrelin in Holstein heifers. J. Endocrinol. 189:655-664.

Van der Honing, Y., and G. Alderman. 1988. Ruminants. Pages 217278 in Livestock Production Science: Livestock Feed Resources and Feed Evaluation in Europe Present Situation and Future Prospects. Vol. 19. F. De Boer and H. Bickel, ed. Elsevier Scientific Pub. Co., Amsterdam, the Netherlands.

Van Es, A. J. H. 1975. Feed evaluation for dairy cows. Livest. Prod. Sci. 2:107.

van Knegsel, A. T., H. van den Brand, J. Dijkstra, and B. Kemp. 2007. Effects of dietary energy source on energy balance, metabolites and reproduction variables in dairy cows in early lactation. Theriogenology 68:S274-S280.

Van Soest, P. J., J. B. Robertson, and B. A. Lewis. 1991. Methods for dietary fiber, and nonstarch polysaccharides in relation to animal nutrition. J. Dairy Sci. 74:3583-3597.

VDLUFA. 1993. Methodenbuch Band III: Die chemische Untersuchung von Futtermitteln. Verband Deutscher Landwirtschaftlicher Untersuchungs-und Forschungsan-stalten (VDLUFA) Verlag, Darmstadt, Germany.

Veerkamp, R. F., J. K. Oldenbroek, H. J. van der Gaast, and J. H. van der Werf. 2000. Genetic correlation between days until start of luteal activity and milk yield, energy balance, and live weights. J. Dairy Sci. 83:577-583.

Vestergaard, E. T., M. Buhl, J. Gjedsted, M. Madsen, N. Jessen, B. D. Nielsen, B. D. Gaylinn, J. Liu, M. O. Thorner, N. Moller, and J. O. Jorgensen. 2011. Acute peripheral metabolic effects of intraarterial ghrelin infusion in healthy young men. J. Clin. Endocrinol. Metab. 96:468-477.

Wathes, D. C., Z. Cheng, W. Chowdhury, M. A. Fenwick, R. Fitzpatrick, D. G. Morris, J. Patton, and J. J. Murphy. 2009. Negative energy balance alters global gene expression and immune responses in the uterus of postpartum dairy cows. Physiol. Genomics 39:1-3.

Weber, C., C. Hametner, A. Tuchscherer, B. Losand, E. Kanitz, W. Otten, S. P. Singh, R. M. Bruckmaier, F. Becker, W. Kanitz, and H. M. Hammon. 2013. Variation in fat mobilization during early lactation differently affects feed intake, body condition, and lipid and glucose metabolism in high-yielding dairy cows. J. Dairy Sci. 96:165-180.

Wertz-Lutz, A. E., T. J. Knight, R. H. Pritchard, J. A. Daniel, J. A. Clapper, A. J. Smart, A. Trenkle, and D. C. Beitz. 2006. Circulating ghrelin concentration fluctuate relative to nutritional status and influences feeding behavior. J. Anim. Sci. 84:3285-3300.

Wylie, A. R. G., S. Woods, A. F. Carson, and M. McCoy. 2008. Peripartal changes in metabolite and metabolic hormone concentrations in high-genetic-merit dairy heifers and their relationship to energy balance in early lactation. J. Dairy Sci. 91:577-586.

Yan, T., F. J. Gordon, R. E. Agnew, M. G. Porter, and D. C. Patterson. 1997a. The metabolisable energy requirement for maintenance and the efficiency of utilisation of metabolisable energy for lactation by dairy cows offered grass silage-based diets. Livest. Prod. Sci. 51:141-150.

Yan, T., F. J. Gordon, C. P. Ferris, R. E. Agnew, M. G. Porter, I. A. Wright, and D. C. Patterson. 1997b. The fasting heat production and effect of lactation on energy utilisation by dairy cows offered forage-based diets. Livest. Prod. Sci. 52:177-186.

Yan, T., C. S. Mayne, W. J. Keady, and R. E. Agnew. 2006. Effects of dairy cow genotype with two planes of nutrition on energy partitioning between milk and body tissue. J. Dairy Sci. 89:1031-1042. 